This item was submitted to Loughborough's Research Repository by the author.

Items in Figshare are protected by copyright, with all rights reserved, unless otherwise indicated.

\title{
Inventories of SO2 and particulate matter emissions from fluid catalytic cracking units in petroleum refineries
}

PLEASE CITE THE PUBLISHED VERSION

http://dx.doi.org/10.1007/s11270-010-0423-z

PUBLISHER

(C) Springer Verlag

VERSION

AM (Accepted Manuscript)

LICENCE

CC BY-NC-ND 4.0

\section{REPOSITORY RECORD}

Yateem, Wael, Vahid Nassehi, and Abdul R. Khan. 2011. "Inventories of SO2 and Particulate Matter Emissions from Fluid Catalytic Cracking Units in Petroleum Refineries”. figshare.

https://hdl.handle.net/2134/7883. 
This item was submitted to Loughborough's Institutional Repository (https://dspace.lboro.ac.uk/) by the author and is made available under the following Creative Commons Licence conditions.

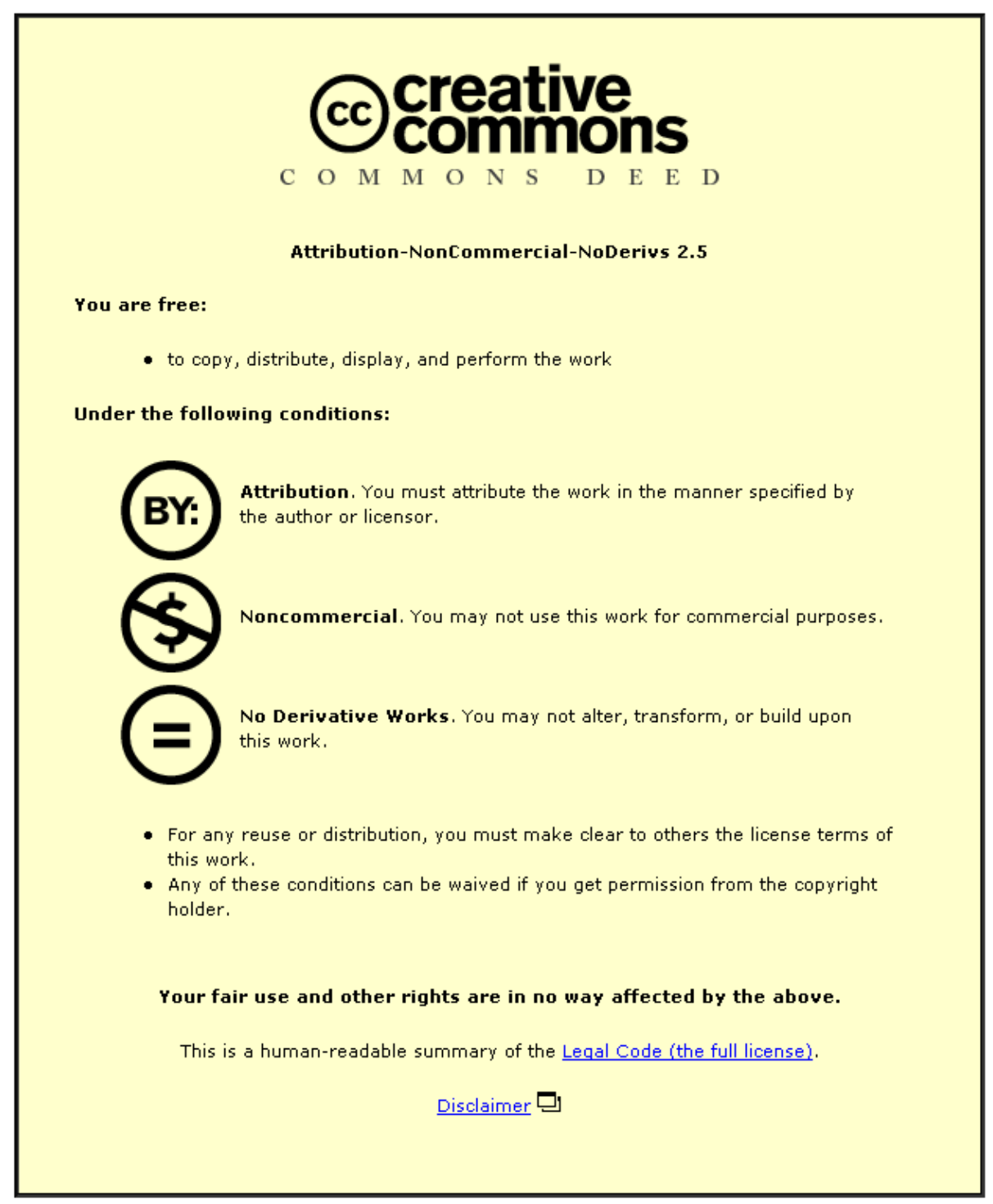

For the full text of this licence, please go to: http://creativecommons.org/licenses/by-nc-nd/2.5/ 


\title{
Inventories of $\mathrm{SO}_{2}$ and particulate matter emissions from Fluid Catalytic Cracking units in petroleum refineries.
}

\author{
Wael Yateem ${ }^{1}$, Vahid Nassehi ${ }^{1}$, Abdul R. Khan ${ }^{2}$ \\ ${ }^{1}$ Department of Chemical Engineering, Loughborough University, Leicestershire, UK, LE11 \\ 3TU. \\ 2 Department of Environment Technology and Management, College for Women, Kuwait \\ University, Kuwait
}

\begin{abstract}
Fluid catalytic cracking (FCC) of heavy ends to high value liquid fuels is a common unit operation in oil refineries. In this process the heavy feedstock which contains sulphur is cracked to light products. Sulphur content is hence redistributed in the liquid and gaseous products and coke of the catalyst used in this process. The coke is later burnt in the regenerator releasing sulphur into the discharged flue gas as $\mathrm{SO}_{2}$. In the present work, comprehensive emission inventories for a FCC unit in a typical oil refinery are prepared. These inventories are based on calculations which assume complete combustion of catalyst coke in the regenerator. Yearly material balances for both $\mathrm{SO}_{2}$ and particulate matters (PM) emissions are carried out taking into account seasonal variations in the operation of the process unit. The results presented in this paper reflect the variation of sulphur in feedstock originating from various units in the refinery. The refinery operations are not dependant on seasons but controlled by market driven conditions to maximize the profit. The seasonal impact on refinery emissions is minimal due to its operation at optimum capacity fulfilling the international market demand. The data presented and analyzed here can be used to assess the hazardous impact of $\mathrm{SO}_{2}$ and particulate matter (PM) emissions on surrounding areas of the refinery.
\end{abstract}

Keywords: Emissions inventory, Particulates, $\mathrm{SO}_{2}, \mathrm{FCC}$, Material balance 


\section{Nomenclature}

$\mathrm{F}=$ feed $(\mathrm{T} / \mathrm{hr})$

$\mathrm{L}=$ total liquid products $(\mathrm{T} / \mathrm{hr})$

$\mathrm{G}=$ total gas products $(\mathrm{T} / \mathrm{hr})$

$\mathrm{E}=$ total emission $(\mathrm{T} / \mathrm{hr})$

$\mathrm{A}=$ total air feed $(\mathrm{T} / \mathrm{hr})$

$\mathrm{M}=$ fresh catalyst $(\mathrm{T} / \mathrm{hr})$

$\mathrm{L}_{2}=$ is heavy cycle oil

$\mathrm{X}_{\mathrm{F} 1}=$ sulphur weight fraction in liquid feed

$\mathrm{x}_{\mathrm{j} 1}=$ sulphur weight fraction in liquid products

$\mathrm{x}_{\mathrm{j} 2}=\mathrm{PM}$ weight fraction in $\mathrm{HCO}$

$\mathrm{y}_{\mathrm{j} 1}=$ sulphur weight fraction in gaseous products

$\mathrm{y}_{\mathrm{E} 1}=$ sulphur weight fraction in flue gases

$\mathrm{y}_{\mathrm{E} 2}=\mathrm{PM}$ weight fraction in flue gases 


\section{INTRODUCTION}

Ever increasing demand for fossil fuels resulting from industrial and economic growth in the modern world has forced the utilization of the state of the art technologies by petroleum refining industry to obtain maximum yield. However, the environmental impact of the unit operations used in this industry is an issue that requires constant monitoring. In this respect the main operation to be considered is processing of crude oil which yields many valuable products such as gasoline, diesel, aviation turbine kerosene, liquefied petroleum gas, etc. Fluid Catalytic Cracking unit (FCC) has been one of the most important conversion processes since 1942. This process which has developed considerably over the years allows refineries to utilize their crude oil resources more efficiently.

Maya-Yescas et al., (2004) described the fluid catalytic cracking (FCC) of heavy ends as a common practice in the oil refining industry, which produces highly valuable fuels. After 60 years of evolution, fluid catalytic cracking (FCC) has become one of the most important oil refining processes, Fig 1. Currently, FCC operates in constrained regions of medium to high conversion, using synthetic catalysts. 


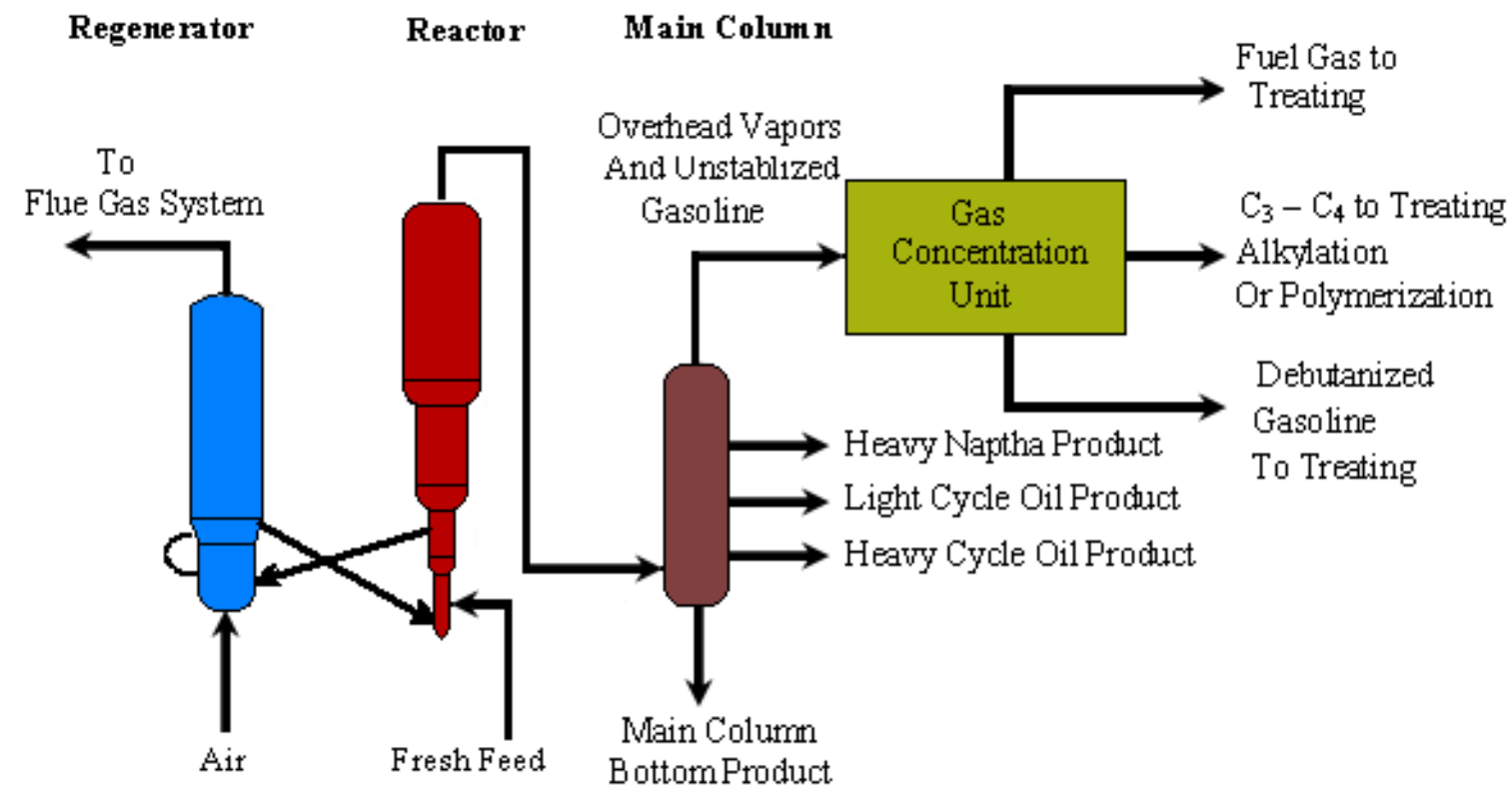

Fig 1: Fluid Catalytic Cracking Process

The main objective FCC unit is to upgrade the low value feedstock to more valuable products. Its heavy feedstock (vacuum gas oil, coker gas oil, unconverted oil and waxy distillate), coming from vacuum unit, delayed coker unit and crude distillation units) respectively is catalytically cracked into lighter products (liquefied petroleum gas, gasoline, diesel and fuel oil). Environmental concerns about this process have increased, during the last 10 years because due to its great contribution of sulfur oxides and particulate matters emissions.

Chen (2006) demonstrated the fluid catalytic cracking (FCC) process technology as a primary conversion unit in the most refineries. It converts low value heavy ends of the crude oil into a variety of higher-value, light products. The primary function of FCC units is to produce gasoline. About $45 \%$ of worldwide gasoline production comes either directly from FCC units or indirectly from combination with downstream units, such as alkylation.

Venuto (1978) showed the most common FCC feedstock as a blend of gas oils, from vacuum and atmospheric distillation and delayed coking. Due to the inherent desulphurization during cracking reactions, that results of breaking of the C-S bonds in the feedstock. Sulphur in the feedstock distributes, mainly to cyclic oils, gasoline, hydrogen sulphide and coke. 
The major units in the FCC process are discussed as a feed preheat section, reactor-regenerator section, main fractionator and gas concentration section.

In the reactor the catalytic cracking endothermic reaction takes place and catalyst is recovered from all products by passing through a set of multistage cyclones. The collected catalyst is sent to the regenerator. The coke impregnated catalyst is re-activated by combustion process producing $\mathrm{SO}_{2}$. This process is exothermic and energy generated and carried with the catalyst to the reactor to facilitate the endothermic catalytic cracking reaction.

Mitchell et al., (1993) studied the deposition of coke onto the catalyst particle during the oil cracking process and the impurities such as metal compounds which also deposited on the surface of the catalyst. Nickel, iron, vanadium and sodium are just a few of the main contaminants that are deposited onto the catalyst particle. These contaminant metals lead to premature catalyst deactivation and the propagation of undesirable reactions which reduce the quality of the product.

Whitcombe et al., (1993) studied the formation of fines in a fluidized catalytic cracker unit (FCCU) due to catalyst attrition and fracture is a major source of catalyst loss. In addition to the generation of fine particles, a significant amount of aerosols have been identified in the stack emission of FCCU's. It was found that major quantities of metal rich aerosols were generated by the thermal shock. This production of fine particles and aerosols is a new phenomenon that can help explain excessive catalyst emissions from operating FCCU's. The addition of cold makeup catalyst stream to the regenerated hot catalyst enhances attrition resulting into large quantity of fines that result into the increase of PM emissions.

The high heat transfer coefficients for fluidized systems responsible for the temperatures uniformity within the reactor and help to provide a proper control of the system. The regenerator objective restores the catalyst activity and supply heat to the reactor by burning off the coke deposited on the spent catalyst. Whereas the main purpose of the fractionators is to desuperheat and recover liquid products from the products vapor. It accomplishes the fractionation by condensing and re-vaporizing the hydrocarbon vapors as they flow upwards. Apart from the bottom product, which is called heavy cycle oil ( $\mathrm{HCO})$, the other products from the main column are light cycle oil (LCO), distillate, heavy gasoline and the overhead vapors, which are 
un stabilized gasoline and lighters. The deposited sulphur in the coke leaves the FCC process as flue gas from the regenerator in the form of $\mathrm{SO}_{2}$, where as $\mathrm{SO}_{2}$ typically accounts for 80 to $90 \%$ of total $\mathrm{SO} 2$.

Akeredolu (1989) discussed the air pollution sources in Nigeria. The particulate matter constitutes the major atmospheric pollution problem. Both anthropogenic and nonanthropogenic sources of particulate matter were found to be important. The Harmattan dust haze constitutes the largest anthropogenic source of particulate matter. Severe visibility reduction and increased incidence of respiratory and chest congestion complaints are recorded during the Harmattan season. Dust remobilization resulting from vehicular traffic on unpaved as well as on unswept paved roads and from fugitive emissions from open surfaces and biomass burning are the major non-anthropogenic sources of particulate matter. Industries generate and emit particulate as well as gaseous pollutants which have manifested significant negative impact at local levels. Atmospheric environment problems such as air pollution and thermal stress are growing in many tropical countries partly on account of their rapid rate of industrialization / urbanization which outpaces the urban planning process.

\section{FLUID CATALYTIC CRACKING PROCESS}

In the present work emission inventories from FCC unit in an oil refinery are calculated. Mainly both $\mathrm{SO}_{2}$ and particulate matters (PM) have been evaluated accurately for a period of one year considering seasonal variations in the operational condition of the FCC unit in a refinery.

Hot feedstock is charged into the reactor through riser where, it comes in contact with hot regenerated catalyst from regenerator. The feedstock vaporizes at a temperature of $730{ }^{\circ} \mathrm{C}$ and catalytically cracked in the reactor. The velocity of the vapor drops in the reactor, due to expansion from riser to the main reactor. The reaction takes place in fluidized bed reactor with uniform temperature. Products with catalyst pass through a set of cyclones to separate the catalyst fines from the products. The spent catalyst from cyclones is returned to the reactor. The coke and sulphur impregnated catalyst is then sent to regenerator to restore its activity. Excess air is fed to the regenerator for complete combustion of coke and sulphur in a fluidized process 
producing flue gas. The flue gas passes through cyclone to recover catalyst particles. Attired catalyst fines are discharged with the exit gas. Flue gas consists of $\mathrm{SO}_{2}, \mathrm{CO}_{2}, \mathrm{~N}_{2}, \mathrm{O}_{2}$ and fines. The activated catalyst at $730{ }^{\circ} \mathrm{C}$ is recharged to the reactor and makeup stream is added to compensate the catalyst loss in the flue gas. The products are sent to the fractionator for further separation.

\section{MATERIAL BALANCE}

To evaluate each stream in FCC unit, overall material balance is established in mass flow rate (T/hr), Fig 2.

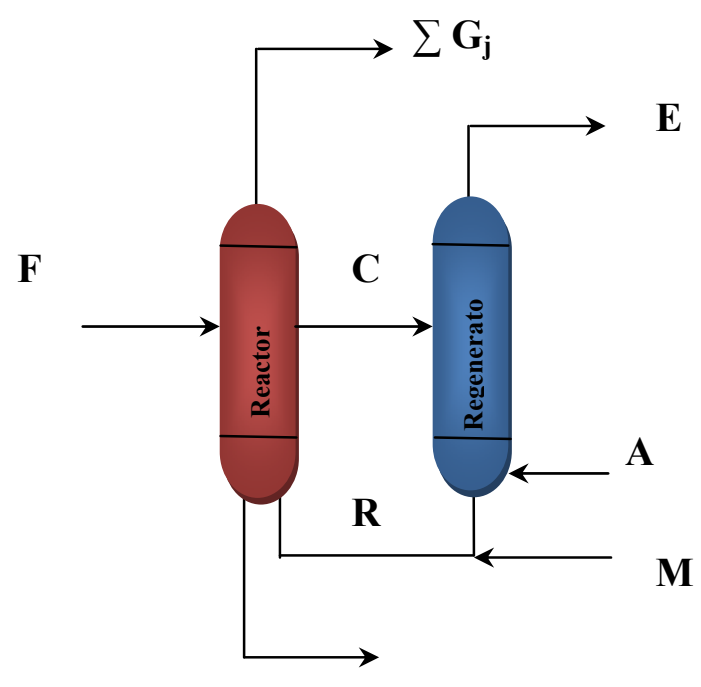

$\sum \mathbf{L}_{\mathbf{j}}$

Fig 2: Overall material balance around reactor and regenerator 
$\mathrm{F}+\mathrm{M}+\mathrm{A}=\mathrm{L}+\mathrm{G}+\mathrm{E}$

\section{Where:}

$\mathrm{F}$ is the total feed consisting of heavy ends from various refining units

$\mathrm{M}$ is makeup catalyst stream

A is the air supplied to the regenerator

$\mathrm{G}$ is a mixture of gaseous products (LPG and Off gas)

$\mathrm{L}$ is liquid products

$\mathrm{E}$ is the flue gas consisting of $\mathrm{CO}_{2}, \mathrm{~N}_{2}, \mathrm{SO}_{2}, \mathrm{O}_{2}$ and particulate matters (PM).

To calculate the emissions, material balance of $\mathrm{i}^{\text {th }}$ component around the FCCU is considered:

For sulphur balance $\mathrm{i}=1$ :

$\mathrm{F} \times \mathrm{x}_{\mathrm{F} 1}=\sum\left(\mathrm{L}_{\mathrm{j}} \times \mathrm{x}_{1 \mathrm{j}}\right)+\sum\left(\mathrm{G}_{\mathrm{j}} \times \mathrm{y}_{1 \mathrm{j}}\right)+\mathrm{E} \times \mathrm{y}_{\mathrm{E} 1}$

For PM balance $\mathrm{i}=2$ :

$M=L_{j} \times x_{2 j}+E \times y_{E 2}$

The operational data for $24^{\text {th }}$ of March 2007 are given as total feed equal to $255.1 \mathrm{~T} / \mathrm{hr}$, with sulphur composition $\left(\mathrm{x}_{\mathrm{F} 1}\right)$ equal to 0.008 . Total liquid and gaseous products are 173.6 and 62.3 $\mathrm{T} / \mathrm{hr}$ respectively. Air fed to the regenerator is calculated based on complete combustion of all coke and sulphur to produced $\mathrm{SO}_{2}$ and $\mathrm{CO}_{2}$ with $10 \%$ excess and is equal to $233.04 \mathrm{~T} / \mathrm{hr}$. Total emission is calculated using equation (1) with known amount of catalyst makeup stream 0.1 $\mathrm{T} / \mathrm{hr}$.

$\mathrm{E}=255.1+0.1+233.04-173.6-62.3=252.4 \mathrm{~T} / \mathrm{hr}$

Sulphur in flue gas, E (252.4 T/hr) is calculated using equation (2) 
$\mathrm{Ey}_{\mathrm{E} 1}=(255.1 \times 0.008)-0.614-0.204=1.222 \mathrm{~T} / \mathrm{hr}$.

$\mathrm{SO}_{2}$ emission is equal to $=1.222 \frac{64}{\mathrm{~g} 2}=2.444 \mathrm{~T} / \mathrm{hr}$

Particulate Matters (PM) in flue gas, E (252.4 T/hr) is calculated using equation (3)

$\mathrm{Ey}_{\mathrm{E} 2}=0.1042-0.0007=0.1035 \mathrm{~T} / \mathrm{hr}$

\section{RESULTS AND DISCUSSION}

$\mathrm{SO}_{2}$ and $\mathrm{PM}$ emissions inventories during the period from December 2007 to November 2008 are calculated for four different seasons. Kuwait is located in the north east of Arabian Peninsula and has four seasons, starting winter season from December till end of February, followed by spring season from March to May. Summer season starts from June till August, followed by autumn season from September to November. Figure 3 illustrates the seasonal temperature variation for the year 2008. In winter season, hourly minimum temperature is $6{ }^{\circ} \mathrm{C}$ recorded on $10^{\text {th }}$ of January at 00:00 hour and the hourly maximum temperature is $26.5^{\circ} \mathrm{C}$ on 20 February at 12:00 hour. The average seasonal temperature in winter is $16{ }^{\circ} \mathrm{C}$. The hourly minimum temperature for spring season is $14.5^{\circ} \mathrm{C}$ measured on $3^{\text {rd }}$ of March at 6:00 hour and the hourly maximum temperature measured is $43{ }^{\circ} \mathrm{C}$ on $22^{\text {nd }}$ of May at 10:00 hour. The average seasonal temperature in spring is $25{ }^{\circ} \mathrm{C}$. In the summer season, hourly minimum temperature is $32{ }^{\circ} \mathrm{C}$ observed on $4^{\text {th }}$ of August at 3:00 hour and the hourly maximum observed in the same season is $48^{\circ} \mathrm{C}$ on $7^{\text {th }}$ of August at 14:00 hour. The average seasonal temperature in summer is $40{ }^{\circ} \mathrm{C}$. The hourly minimum temperature recorded in autumn season is $9{ }^{\circ} \mathrm{C}$ on $24^{\text {th }}$ of November at 6:00 hour and the hourly maximum temperature recorded is $35.5{ }^{\circ} \mathrm{C}$ on $14^{\text {th }}$ of October at 12:00 hour. The average seasonal temperature in the autumn is $28{ }^{\circ} \mathrm{C}$. 


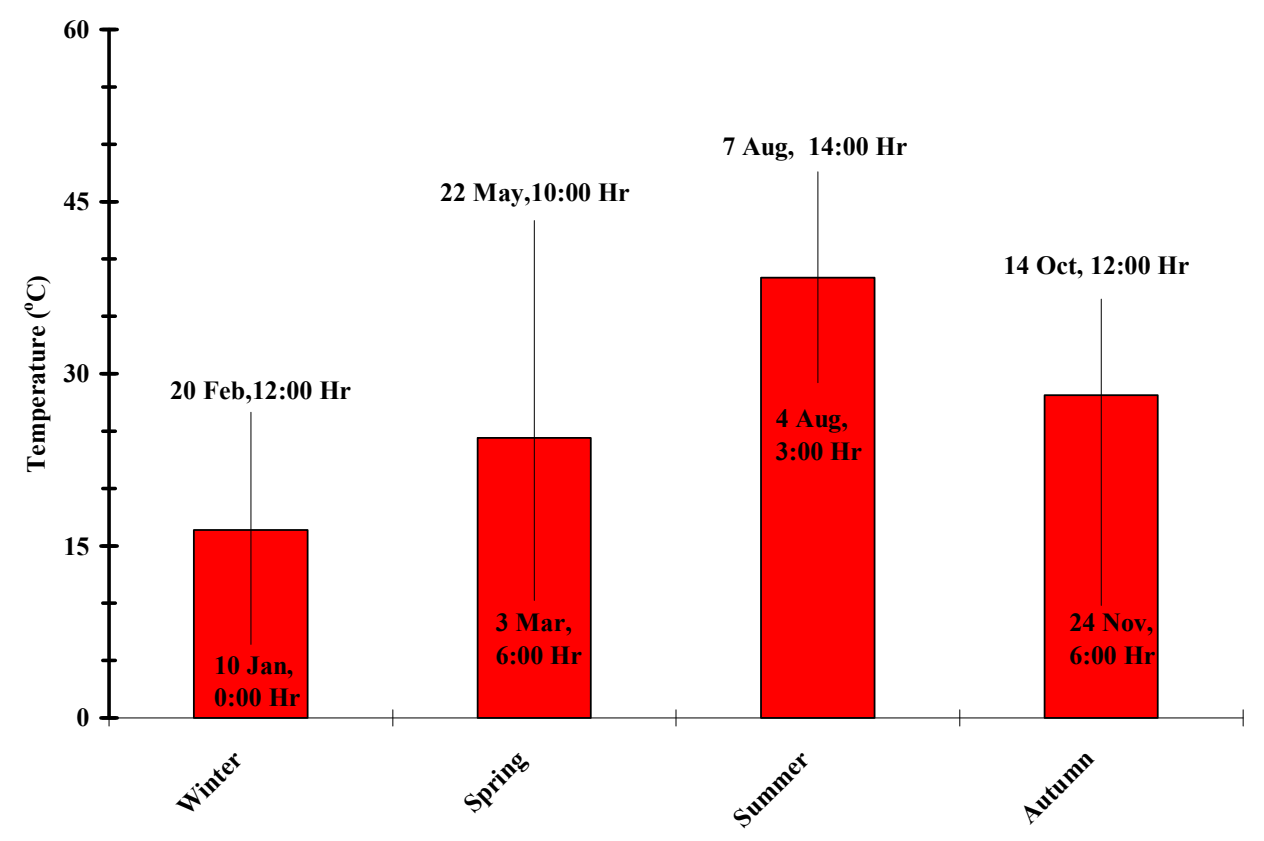

Fig. 3: Hourly Maximum, Minimum and seasonal Average Temperatures in Kuwait

Figures 4 to 11 shows all the emission variation of $\mathrm{SO}_{2}$ and $\mathrm{PM}$ for different seasons respectively.

In winter season, the emission rates are evaluated from operational data for 11 weeks and the maximum value is $529.2 \mathrm{~g} / \mathrm{sec}$ on $2^{\text {nd }}$ of December 2007 and the minimum value is 376.4 $\mathrm{g} / \mathrm{sec}$ on $9^{\text {th }}$ of December 2007. The emission rate for the entire period is $479.3 \pm 2 \sigma \mathrm{g} / \mathrm{sec}$, where standard deviation is equal to $45.9 \mathrm{~g} / \mathrm{sec} . \mathrm{SO}_{2}$ emissions rates for spring season are observed providing maximum value of $679.17 \mathrm{~g} / \mathrm{sec}$ on $24^{\text {th }}$ of March 2008 , which is higher than the winter maximum emission rate. The minimum calculated value is $356.39 \mathrm{~g} / \mathrm{sec}$ on $26^{\text {th }}$ of May 2008, which is lower than the winter minimum value. The emission rate for 13 weeks is $559.1 \pm 2 \sigma \mathrm{g} / \mathrm{sec}$, where standard deviation is equal to $90.42 \mathrm{~g} / \mathrm{sec}$. The maximum value for $\mathrm{SO}_{2}$ emissions rates is found to be $654.17 \mathrm{~g} / \mathrm{sec}$ on $2^{\text {nd }}$ of June 2008, which is lower than the spring maximum value but higher than the winter maximum value. For the summer season, the minimum emission rate is $403.89 \mathrm{~g} / \mathrm{sec}$ same on $7^{\text {th }}$ of July and $21^{\text {Ist }}$ of August 2008, which is 
higher than both winter and spring minimum values. For summer season the emission rate calculated for 11 weeks is $458.30 \pm 2 \sigma \mathrm{g} / \mathrm{sec}$, where standard deviation is equal to $77.04 \mathrm{~g} / \mathrm{sec}$. $\mathrm{SO}_{2}$ emissions rates for autumn season are evaluated for 12 weeks. The maximum value is $653.4 \mathrm{~g} / \mathrm{sec}$ on $23^{\text {rd }}$ of September 2008, which is almost similar to maximum value during spring season. The minimum computed value is $357.17 \mathrm{~g} / \mathrm{sec}$ on $5^{\text {th }}$ of October 2008 which is similar to the minimum value of spring season. The emission rate for whole autumn period is $540.1 \pm 2 \sigma \mathrm{g} / \mathrm{sec}$, where standard deviation is equal to $91.51 \mathrm{~g} / \mathrm{sec}$.

In winter season emission rates are consistent with minimum fluctuation, while in spring season the emission rates are high in the beginning of the season then decreasing gradually. Whereas in summer season the emission rates are high at the start of the season and later become almost constant. Finally variation in emission rates is lower in beginning of the autumn season then increased. The highest and the lowest emission rates in all seasons reflect the operational conditions, mainly sulphur contents in the feedstock and the total amount of heavy ends charged to the FCCU.

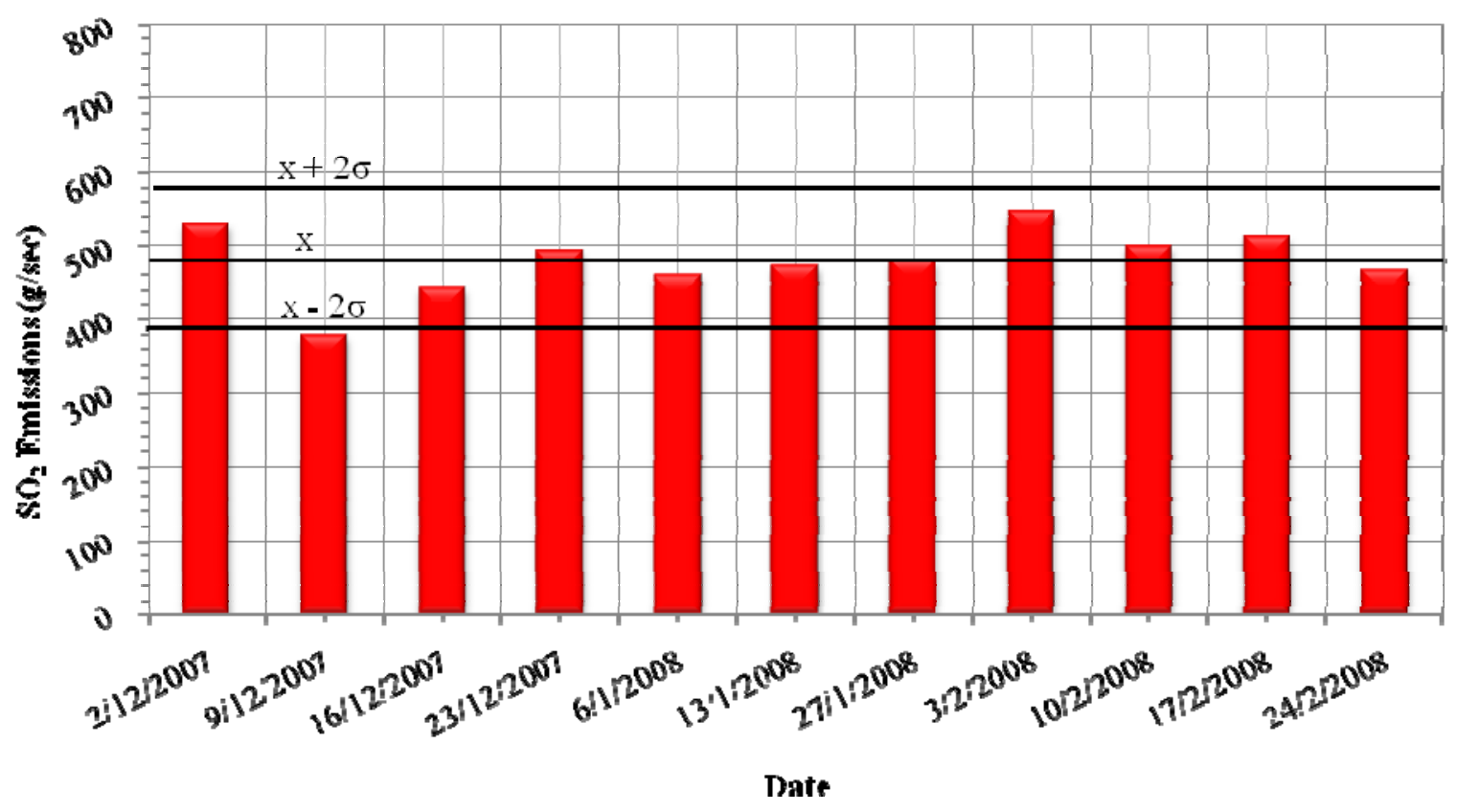

Fig 4: $\mathrm{SO}_{2}$ emission rates $(\mathrm{g} / \mathrm{sec})$ for winter season 


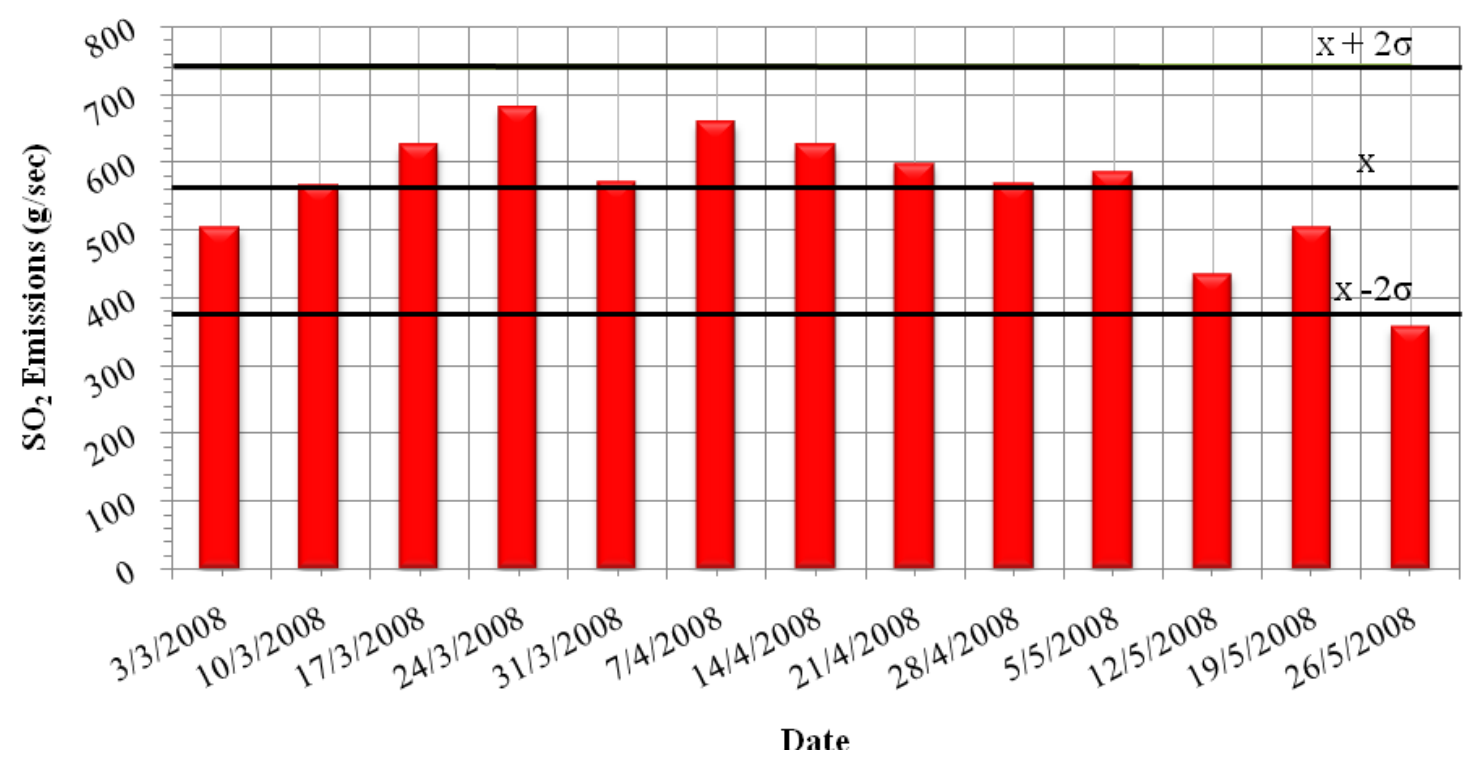

Fig 5: $\mathrm{SO}_{2}$ emission rates $(\mathrm{g} / \mathrm{sec})$ for spring season

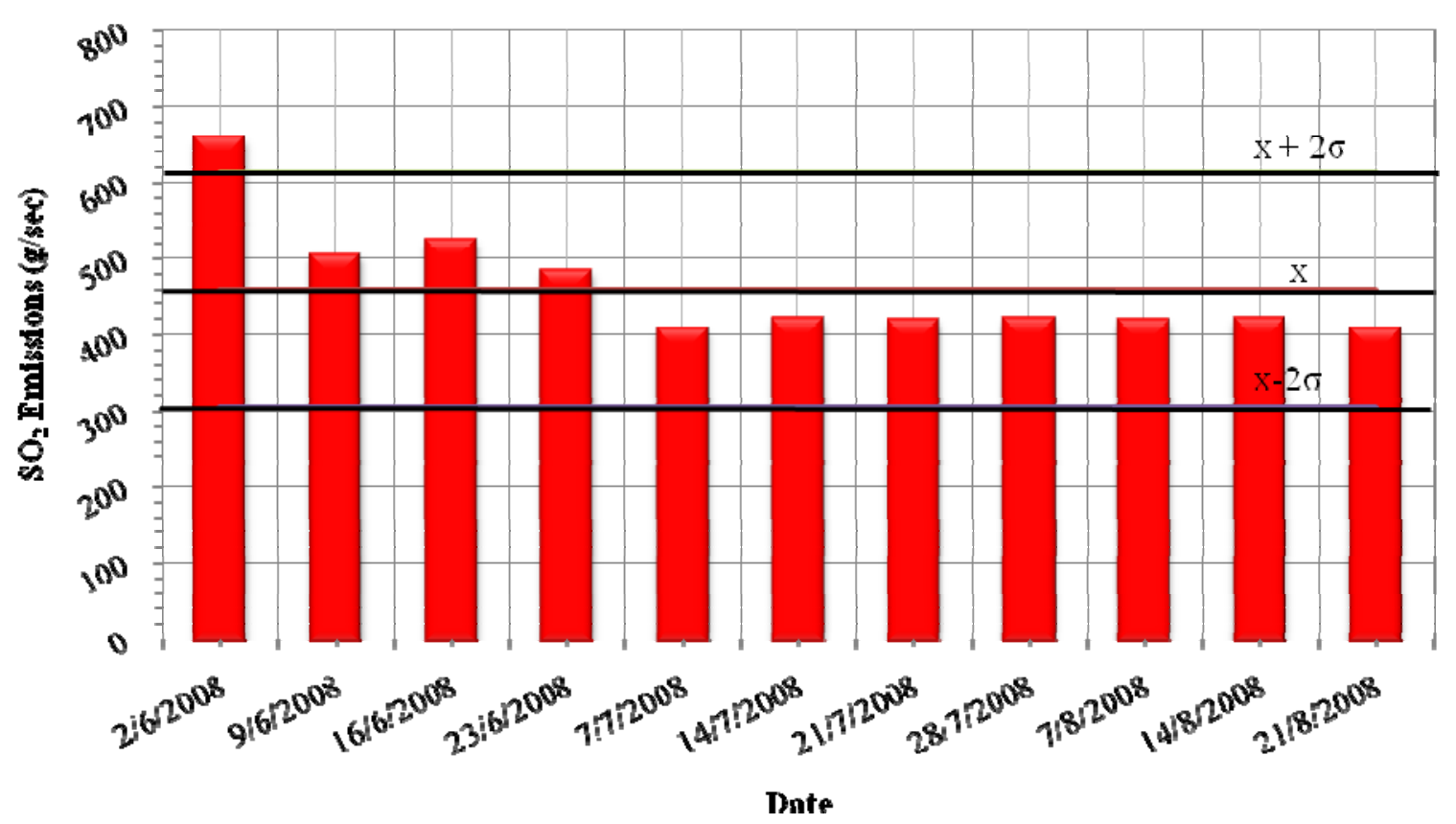

Fig 6: $\mathrm{SO}_{2}$ emission rates $(\mathrm{g} / \mathrm{sec})$ for summer season 


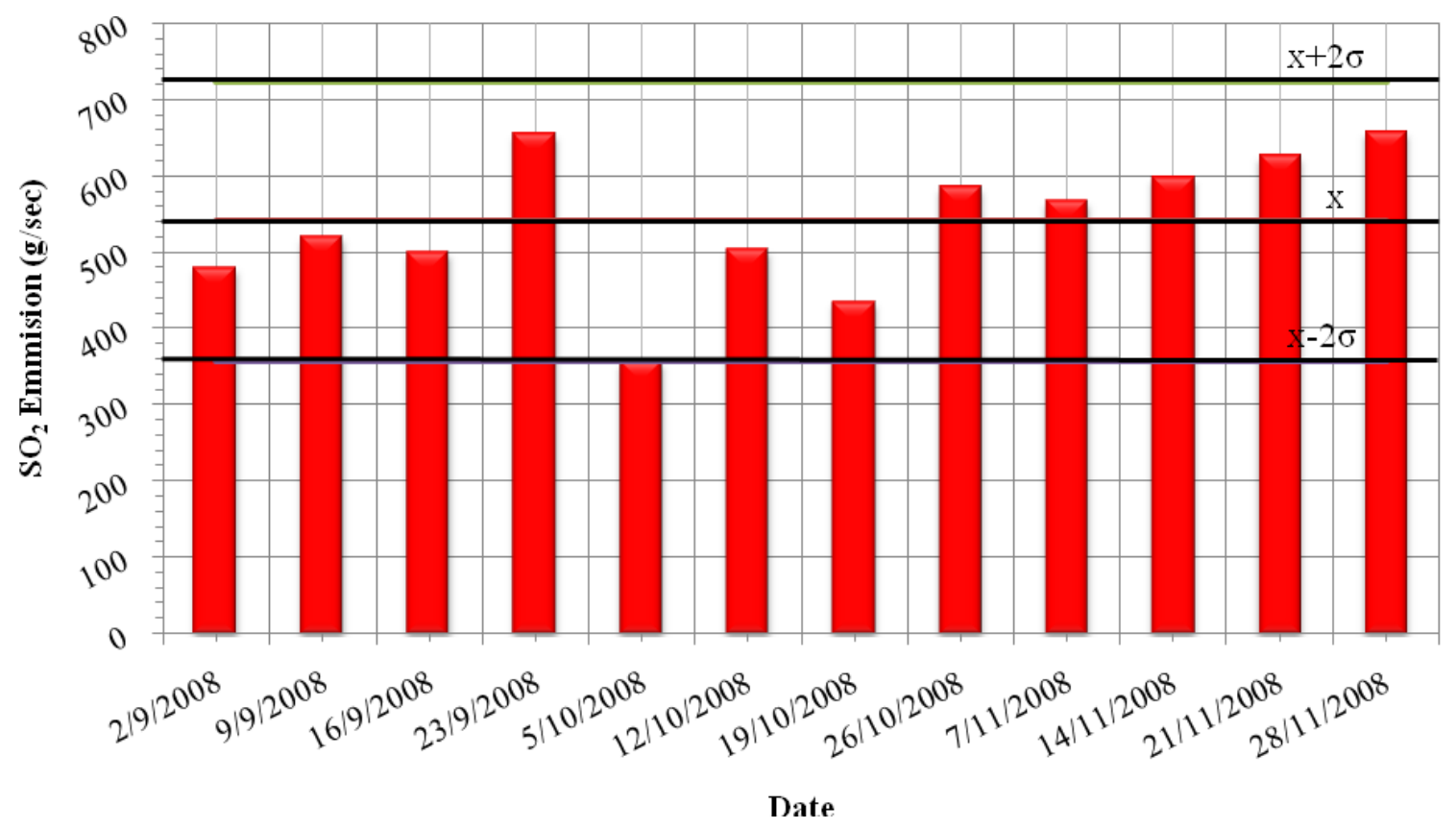

Fig 7: $\mathrm{SO}_{2}$ emission rates $(\mathrm{g} / \mathrm{sec})$ for autumn season

Similarly the PM emissions related to the process operating conditions. Figures 8 to 11 show the behavior of PM emissions during different seasons. The maximum value is 39.17 $\mathrm{g} / \mathrm{sec}$ on $13^{\text {th }}$ of January 2008 and the minimum value is $23.06 \mathrm{~g} / \mathrm{sec}$ on $23^{\text {rd }}$ of December 2007 for winter season. The emission rate in this season is $26.6 \pm 2 \sigma \mathrm{g} / \mathrm{sec}$ where standard deviation is $5.63 \mathrm{~g} / \mathrm{sec}$. Similarly PM emission rates for spring season are calculated providing maximum value of $28.06 \mathrm{~g} / \mathrm{sec}$ on $17^{\text {th }}$ of March 2008, which is lower than winter maximum value. The minimum value is $23.89 \mathrm{~g} / \mathrm{sec}$ on two occasions, $12^{\text {th }}$ and $26^{\text {th }}$ of May 2008 . The emission rate for 13 weeks is $25.45 \pm 2 \sigma \mathrm{g} / \mathrm{sec}$, where standard deviation is equal to $1.79 \mathrm{~g} / \mathrm{sec}$. the minimum calculated values for both winter and spring seasons are almost similar. For summer season the maximum value for PM emissions rates is $26.39 \mathrm{~g} / \mathrm{sec}$ on three consecutive occasions, $2^{\text {nd }}, 9^{\text {th }}$, and $16^{\text {th }}$ of June 2008 . Whereas the minimum computed value is $18.06 \mathrm{~g} / \mathrm{sec}$ on $14^{\text {th }}$ of July and $14^{\text {th }}$ of August 2008. The emission rate calculated for 11 weeks is $21.72 \pm 2 \sigma \mathrm{g} / \mathrm{sec}$, where standard deviation is equal to $3.41 \mathrm{~g} / \mathrm{sec}$. Finally PM emissions rates for autumn season are evaluated for 12 weeks. The maximum value found to be $26.7 \mathrm{~g} / \mathrm{sec}$ on three consecutive occasions, $09^{\text {th }}, 16^{\text {th }}$ and $23^{\text {rd }}$ September 2008 . While the minimum computed value is $23.5 \mathrm{~g} / \mathrm{sec}$ on $5^{\text {th }}$ and $19^{\text {th }}$ of October 2008 . The emission rate for whole autumn period is $24.68 \pm 2 \sigma \mathrm{g} / \mathrm{sec}$, 
where standard deviation is equal to $1.040 \mathrm{~g} / \mathrm{sec}$. The highest PM maximum value is in the winter season and the lowest value is in the summer season, while minimum emission rate is similar to the maximum emission values, high in winter and low summer seasons.

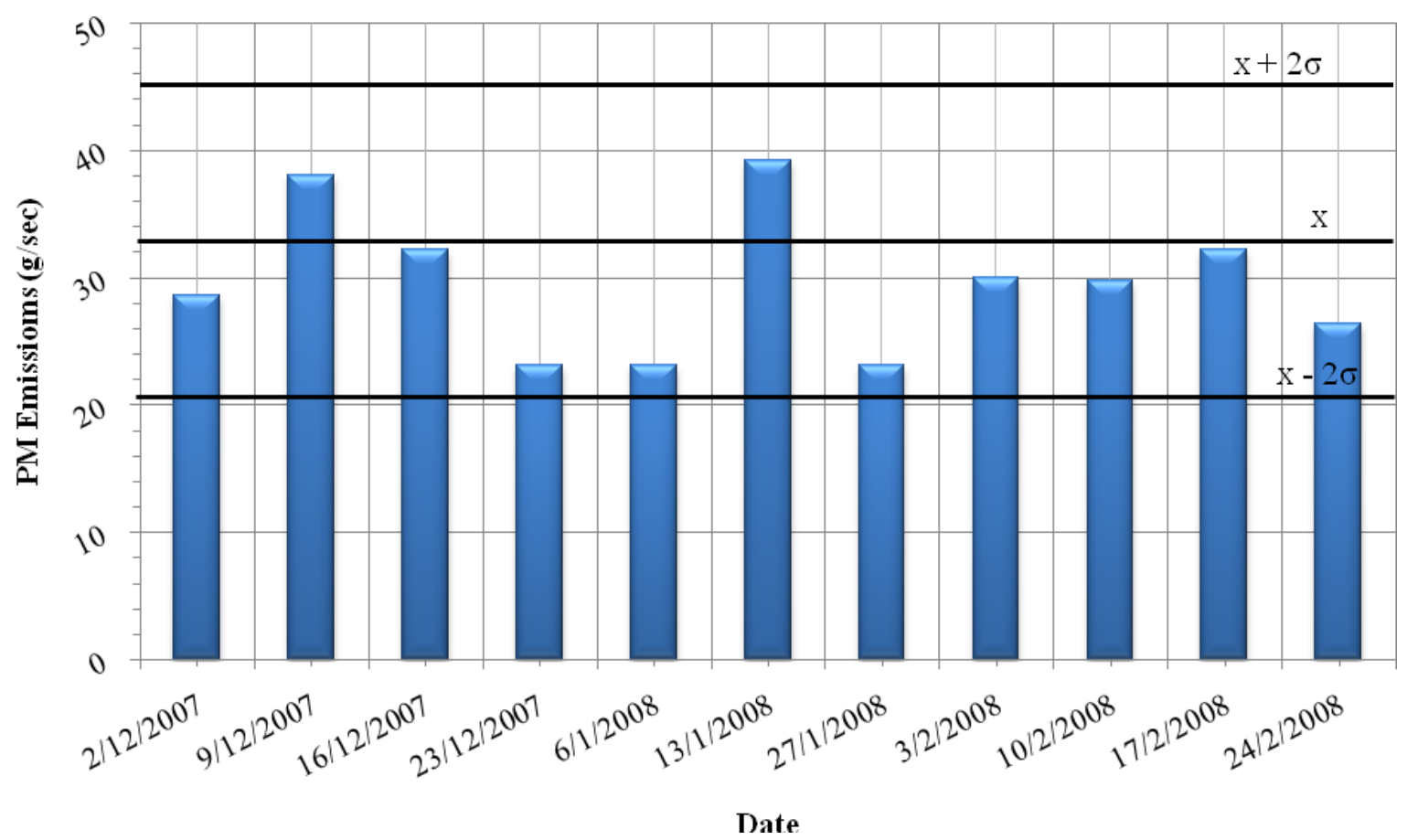

Fig 8: Particulate Matter (PM) emissions rates $(\mathrm{g} / \mathrm{sec})$ for winter season 


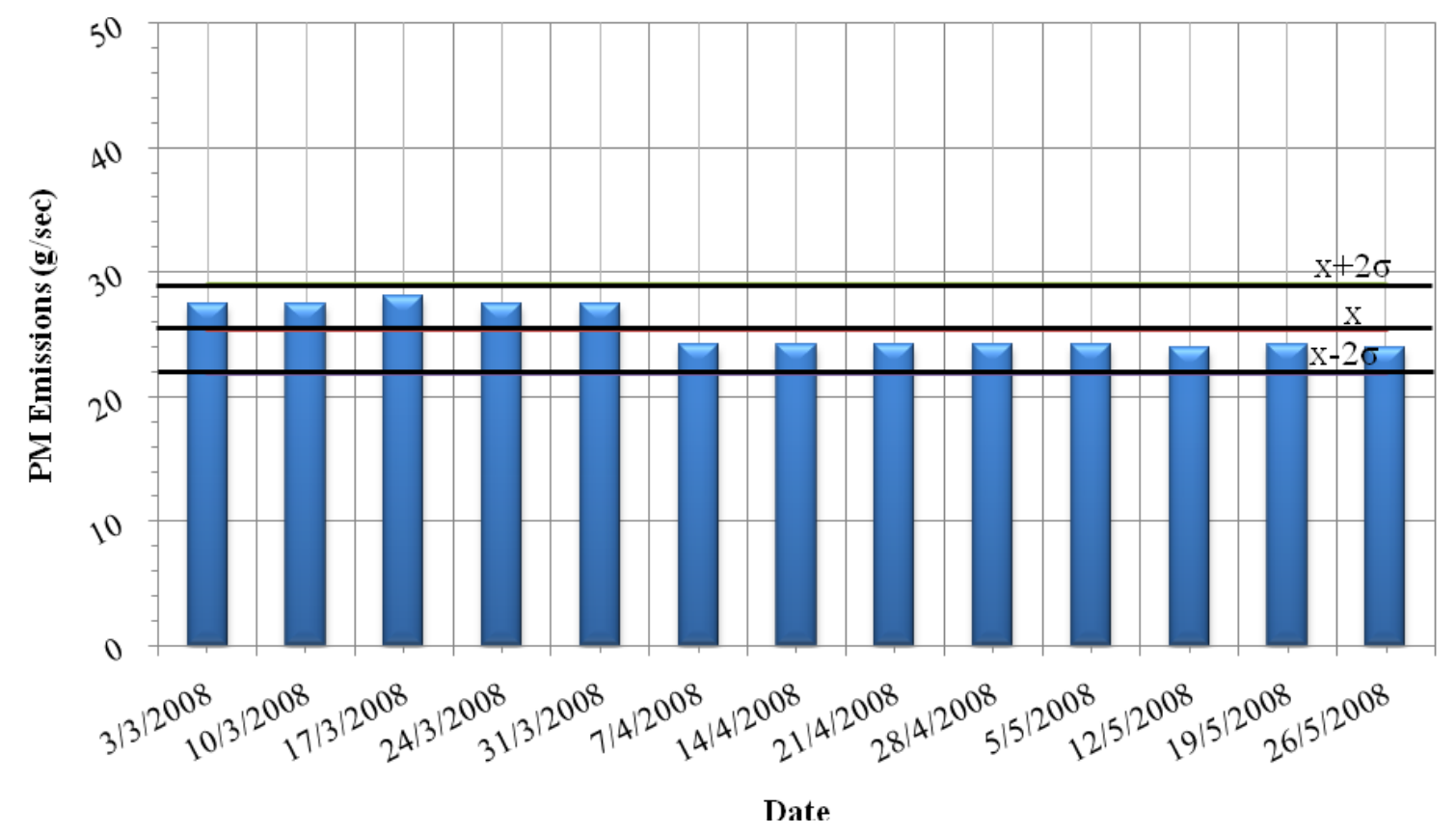

Fig 9: Particulate Matter (PM) emissions rates (g/sec) for spring season

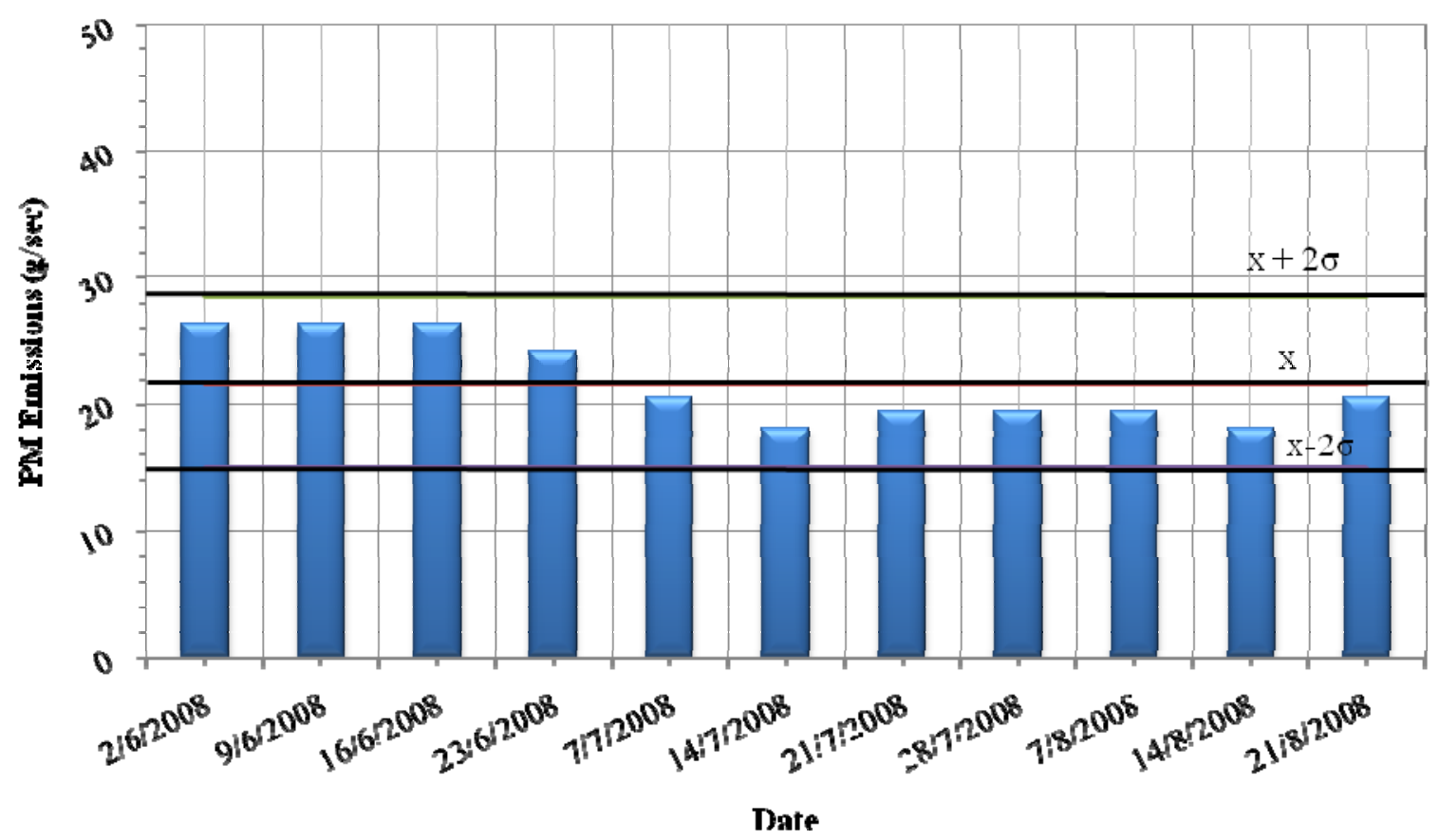

Fig 10: Particulate Matter (PM) emissions rates (g/sec) for summer season 


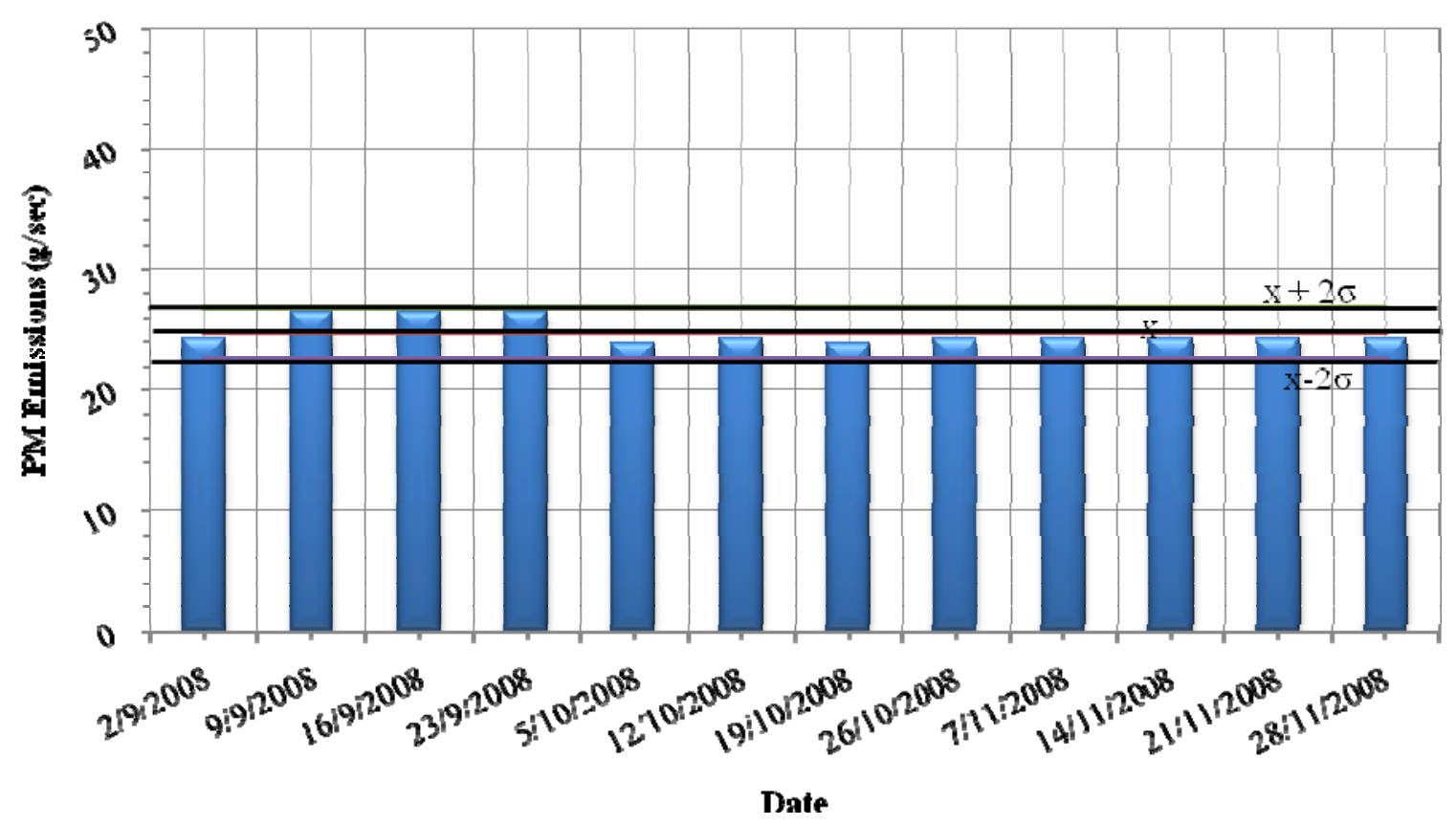

Fig 11: Particulate Matter (PM) emissions rates $(\mathrm{g} / \mathrm{sec})$ for autumn season

\section{CONCLUSION}

FCC unit in a refinery is major contributor of $\mathrm{SO}_{2}$ and $\mathrm{PM}$ emissions those are responsible for adverse impact on the immediate neighborhood of the refinery. A complete comprehensive emission inventories for a year long period have been prepared for both $\mathrm{SO}_{2}$ and Particulate Matters. The refinery operations are not dependant on seasons but controlled by market driven conditions to maximize the profit. The seasonal impact on refinery emissions is minimal due to its operation at optimum capacity fulfilling the international market demand.

$\mathrm{SO}_{2}$ emissions are high in spring while $\mathrm{PM}$ emissions are high in winter, mainly due to operational conditions that are dependent on feed rate, sulphur contents in the feed. PM emissions are mainly due to high attrition of cold makeup catalyst charge and operating conditions, vapour velocity particle velocity, particle collision and particle degradation. 
These inventories will be used in air dispersion model to thoroughly investigate the impact of FCC unit emissions in the vicinity of the petroleum refinery. Different mitigation methods will be examined to abate the high concentrations of $\mathrm{SO}_{2}$ and $\mathrm{PM}$ emissions from $\mathrm{FCC}$ unit.

\section{REFERENCES}

Funso Akeredolu, 1989, "Atmospheric Environment Problems In Nigeria-An Overview", Atmospheric Enubonmmt Vol. 23, No. 4, pp. 783-792

M.M. Mitchell Jr., J.F. Hoffman, H.F. Moore, Residual feed cracking catalyst, in: J.S. Magee, J.M.M. Mitchell (Eds.), Fluid Catalytic Cracking: Science and Technology, Studies in Surface Science and Catalysis, vol. 76, Elsevier, USA, 1993, pp. 293-338.

J.M. Whitcombe, I.E. Agranovski*, R.D. Braddock 2003" Attrition due to mixing of hot and cold FCC catalyst particles” Powder Technology 137 (2003) 120 - (2003) - 130

McInnes, G., 1996. Joint EMEP/CORINAIR Atmospheric Emission Inventory Guidebook, first ed. European Environmental Agency, Copenhagen, Denmark.

P. B Venuto, E.T Habib, Catalyst-feedstock-engineering interactions in fluid catalytic cracking, Catal. Rev., sci. eng. 18 (1978) 1-150.

R. Maya-Yescasa, E.F. Villafuerte-Macias, R. Aguilarb, D. Salazar-Sotelod, 2004 "Sulphur oxides emission during fluidized-bed catalytic cracking" Chemical Engineering Journal 106, $145-152$

Ye-Mon Chen March 2006 "Recent advances in FCC technology" Powder Technology 163, 2 8

X. Zhao, A.W. Peters, G.W. Weatherbee, Ind. Eng. Chem. Res. 36 (1997) 4535. 